\title{
THE GENDERED IMPACT OF EXPLOSIVE WEAPONS USE IN POPULATED AREAS IN YEMEN
}


The war in Yemen has been marked by the use of explosive weapons in populated areas, often in serious violation of International Humanitarian Law. Such use of explosive weapons has a gendered impact, affecting men and women differently. The longer-term social, psychological and economic impacts fall most heavily on women, with serious consequences for all civilians. In particular, their use in populated areas causes death and injury, damage to infrastructure and services, and drives displacement. Controlling the supply and use of explosive weapons is a quick way to reduce human suffering in Yemen.

\section{(C) Oxfam International November 2019}

This paper was written by Martin Butcher, Oxfam Policy Advisor on Conflict, International Humanitarian Law and Arms. Oxfam acknowledges the assistance of the International Network on Explosive Weapons, Save the Children and Action on Armed Violence in its production. It is part of a series of papers written to inform public debate on development and humanitarian policy issues.

For further information on the issues raised in this paper please email advocacy@oxfaminternational.org

This publication is copyright but the text may be used free of charge for the purposes of advocacy, campaigning, education, and research, provided that the source is acknowledged in full. The copyright holder requests that all such use be registered with them for impact assessment purposes. For copying in any other circumstances, or for re-use in other publications, or for translation or adaptation, permission must be secured and a fee may be charged. Email policyandpractice@oxfam.org.uk.

The information in this publication is correct at the time of going to press.

Published by Oxfam GB for Oxfam International under ISBN 978-1-78748-532-7 in November 2019.

DOI: $10.21201 / 2019.5327$

Oxfam GB, Oxfam House, John Smith Drive, Cowley, Oxford, OX4 2JY, UK.

Front cover photo: Soud, a mother of three, lives in the Jabal Zaid internal displacement camp and suffers from a physical disability. She has been disabled since she experienced trauma after two of her children were killed by an airstrike while they were playing at the back of the family's tent. Soud has also lost two other children to measles. Oxfam is providing humanitarian assistance to people in the camp, including unconditional cash distribution, water trucking, construction and rehabilitation of latrines, hygiene kit distribution, and health awareness sessions. Photo: VFX ADEN/Oxfam.

Back cover photo: Fatima, who fled the fighting with her family in 2015, holds her son's photo. He was killed by an airstrike when they were trying to find safety away from the conflict's frontlines. Photo: VFX ADEN/Oxfam. 


\section{CONTENTS}

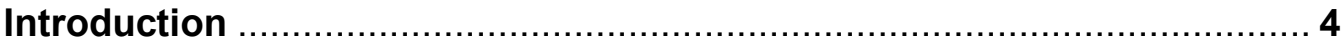

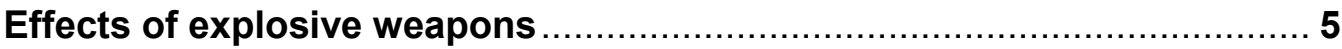

Detailed effects of weapons types in use in Yemen............................ 6

Examples of explosive weapons use in Yemen ................................... 7

Gendered impact of explosive weapons use on women ........................ 8

Effects of the conflict on women in Yemen ........................................ 9

Gendered impact of explosive weapons use on men ......................... 11

Impact of explosive weapons on children .......................................... 12

A closing political space for women ....................................................... 13

Protection of civilians and the use of explosive weapons in populated areas

Policy considerations 14

Notes 16 
The war in Yemen, especially since the commencement of the intervention by the Saudi and UAE-Led Coalition, has been marked by the use of explosive weapons in populated areas. The Coalition has used airstrikes on a massive scale. Houthi forces have routinely shelled urban areas, both in Yemen and across the border in Saudi Arabia. The conflict has also seen the common use of artillery rockets, mortars, rocketpropelled grenades and, increasingly, many types of improvised explosive devices (IEDs).

The use of explosive weapons in Yemen has a gendered impact, affecting men and women differently, and serious consequences for all civilians. Restrictions on delivery of food, fuel and medicines by sea and air have also contributed very significantly to civilian harm in the conflict, and continue to do so. This paper focuses on the use of explosive weapons in populated areas as this causes a huge proportion of the damage to infrastructure and services such as transport, power, water distribution, education and food supply, as well as causing the majority of displacements of Yemeni people. Controlling the supply and use of these weapons is the best way to prevent further human suffering in Yemen.

In considering the transfer of explosive weapons, some States are obliged by the Arms Trade Treaty to consider the risk of violations of International Humanitarian Law (IHL), and all States have a legal obligation not to facilitate breaches of IHL. ${ }^{1}$ Direct attacks on civilians are war crimes. Indiscriminate attacks - where there is no effort to distinguish between civilians and military targets, or where such distinction is impossible because of the indiscriminate nature of the weapons being used, the size of the explosive yield or the proximity of civilians to military targets - can amount to a violation of international law. Under the Arms Trade Treaty, States must also consider the risk of gender-based violence (GBV). This requires a risk assessment that goes beyond violations of International Humanitarian Law and considers potential uses of explosive weapons which may not constitute illegal attacks, but which do constitute or result in serious incidents of GBV. The widespread use of explosive weapons with wide area effects in populated areas of Yemen, even when targeted against military objectives, has contributed to high levels of civilian death and injury, and damage to civilian infrastructure and services including housing, schools, hospitals and medical facilities. In most cases this will be disproportionate to the military advantage achieved, and has contributed to a pattern of harm that has seen the conflict become the world's worst humanitarian disaster.

All of this runs directly counter to the principle of the Protection of Civilians in conflict, which goes beyond not committing war crimes or other violations of International Humanitarian Law and International Human Rights Law to require positive action to ensure that all feasible precautions are taken to avoid and minimize civilian harm ${ }^{2}$ in the conduct of military operations. In Yemen, this principle is not adhered to.

\section{Oxfam recommends:}

- Combatants should avoid the use of explosive weapons in populated areas.

- Governments should support the development of an international political declaration to clarify International Humanitarian Law and reduce the use of explosive weapons.

- Arms suppliers must assess the risk of GBV and violence against women and children, including in combat, as per Arms Trade Treaty obligations.

- The UN Security Council and combatant parties must develop a fully inclusive peace process, based on the model of the National Dialogue. 
- All arms suppliers must ensure that civilian casualty reporting is integral to assessments of explosive weapons use, feeding into risk assessments for future weapons transfers.

- States not party to the Arms Trade Treaty must abide by their obligations under International Humanitarian Law regarding civilian harm.

- Combatant parties must keep better records of civilian casualties and harm, and make this part of a fuller investigation of potential violations of international law to enhance accountability.

- The UN and donors must provide assistance to survivors, including gender- and age-sensitive mental health and psychosocial support.

\section{EFFECTS OF EXPLOSIVE WEAPONS}

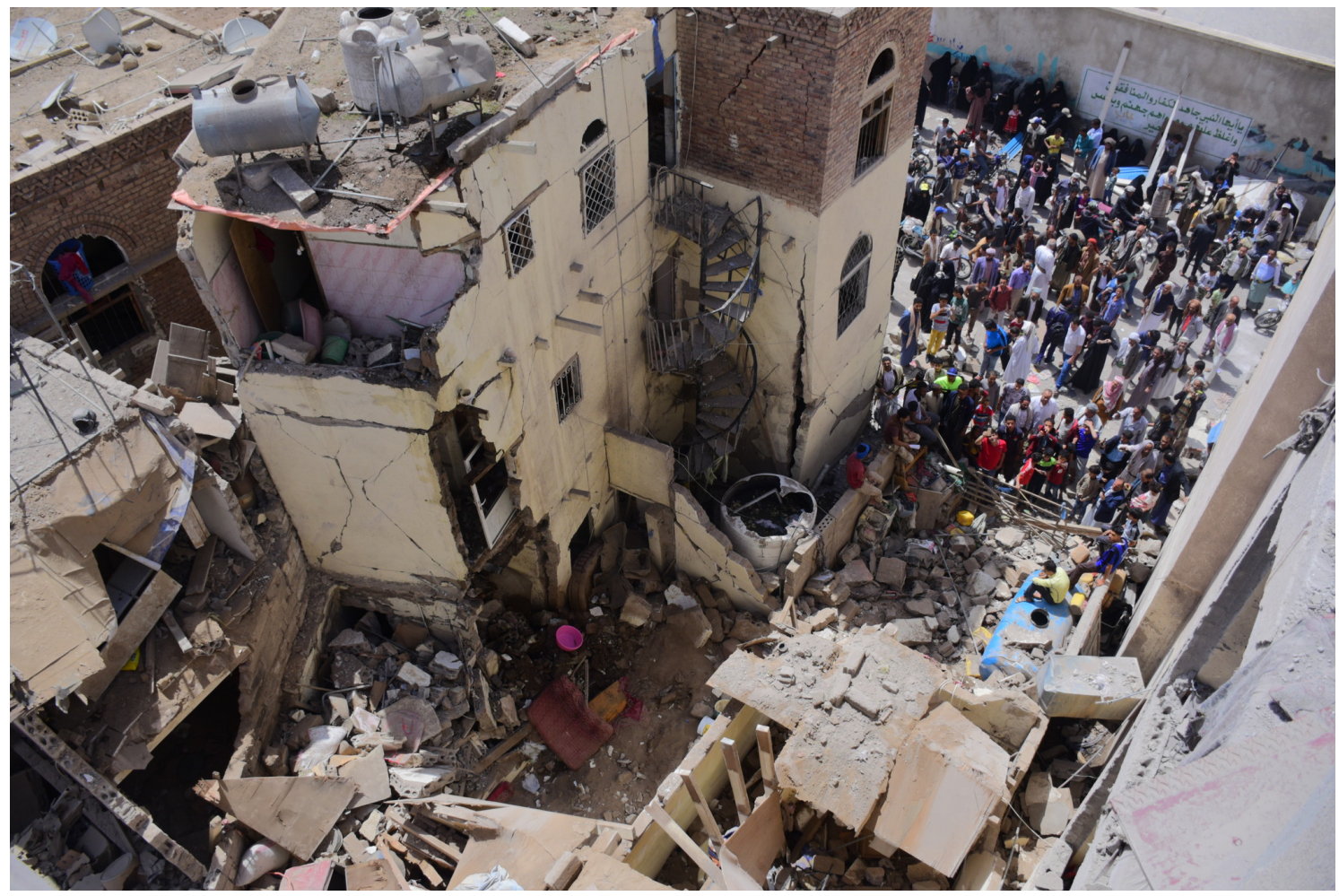

Civilian homes destroyed by airstrikes in Sanaa, May 2019. Photo: Bassam Al-Thulaya/Oxfam in Yemen.

Explosive weapons project blast waves, heat and fragmentation, killing and injuring people in the area around the point of detonation as well as damaging objects, buildings and infrastructure. When used in populated areas they tend to cause high levels of harm to individuals and communities. Children are particularly vulnerable. ${ }^{3}$ Destruction of infrastructure that is vital to the civilian population, including water and sanitation, housing, schools and hospitals, results in a pattern of wider, reverberating harm and long-term suffering. Survivors of explosive weapons effects can face longterm challenges including disability, psychological harm, and social and economic exclusion. Of particular concern are explosive weapons with wide area effects, such as bombs dropped from aircraft or artillery shells and rockets. These cause death, injury and destruction of infrastructure at a great distance from the point of impact, even if aimed precisely at a legitimate military target and, in an urban setting, have indiscriminate effects. Together with the combination of effects from blast, heat and fragmentation, this creates a high risk of severe harm to civilians which must be considered. This should lead all States to put in place policies to avoid the use of 
explosive weapons with wide area effects in populated areas, while exporting States must consider how such weapons will be used. ${ }^{4}$

Primary effects of explosive weapons are defined as those "caused directly by the destructive effects that radiate from a point of initiation and include blast overpressure, fragmentation, heat and light'. ${ }^{5}$ The term 'blast' refers to a high-pressure blast wave moving at supersonic speed, referred to as the shockwave, which is followed by blast winds. Primary fragmentation comprises fragments that originate directly from the explosive munition. The third damage mechanism is the thermal energy released during the detonation of the explosive.

Secondary effects of explosive weapons derive from the environment in which the munition detonates. The most significant secondary effects include secondary fragmentation, firebrands, ground shock and cratering. Secondary fragmentation originates from objects that have been affected by the detonation, and can include objects such as pieces of masonry or glass from buildings, or bone fragments from human or animal targets. Secondary fragments are generally larger than primary fragments and tend not to travel as fast, or as far.

Tertiary effects can be classified as damage to health, social and economic infrastructure and services that occur over a longer time scale, e.g. the lack of clean water caused by damage to water mains and sewers, or the loss of electrical and gas services. Added to these long-term effects are the dangers posed by unexploded ordnance, which can kill or injure people many years after the conflict has ended and prevent use of or access to the areas they contaminate, often depriving populations of valuable farming land. These longer-term effects are increasingly being researched and documented but are not yet well understood. Additional long-term effects on casualties will become apparent as, with better understanding of blast injuries and swifter treatment, some survivors will live longer and with profound effects that will be lifelong.

\section{DETAILED EFFECTS OF WEAPONS TYPES IN USE IN YEMEN}

The effects of explosive and other conventional weapons in urban areas are well understood. Western militaries use sophisticated modelling software to simulate these effects as part of combat training and mission preparation, and an understanding of weapons effects is an integral part of training. ${ }^{6}$ However, this is only possible for preplanned missions, which in Yemen have long made up a minority of airstrikes. The ability to model explosive effects confers, if anything, a greater responsibility on wellresourced armed forces to exercise the utmost caution not only in obeying international law but in avoiding harm to civilians to the maximum extent possible. Collateral Damage Estimation (CDE) methodologies only give an estimate to guide decisions, rather than a prediction of the outcome. CDEs allow military necessity to be weighed against humanitarian harm, but the emphasis in these calculations is on the destruction of the target rather than on the effects of the weapon on civilians and civilian objects. There are many instances of western militaries undertaking strikes which cause high levels of civilian harm, where they consistently claim compliance with International Humanitarian Law. Clearly more needs to be done, given the high levels of civilian casualty and destruction of infrastructure in modern warfare. ${ }^{7}$

Supplied by the US, UK, Italy and other States to the Saudi and UAE-Led Coalition members, the Mark 84 bomb has been used in airstrikes throughout the Coalition's intervention, in thousands of instances. It has both GPS and laser guidance kits. The 
bomb weighs $2,000 \mathrm{lb}$. It has a lethal radius of $360 \mathrm{~m}$ from the point of impact, and can cause injury from fragmentation or blast at distances of up to $800 \mathrm{~m} .{ }^{8}$

For $155 \mathrm{~mm}$ high explosive artillery shells, the most typical modern type, which is used by both Houthi and Coalition forces, the lethal radius of an explosion is $50 \mathrm{~m}$, with injury likely up to $100 \mathrm{~m}$. Artillery shells are typically fired in bursts to cover a wide area. ${ }^{9}$

Many types of multiple launch rocket systems are in use in Yemen, such as the Russian origin BM30 Smerch $330 \mathrm{~mm}$ rocket launcher. ${ }^{10} \mathrm{~A}$ more common variety, hundreds of which have been used in Yemen, is the BM21 Grad multiple launch rocket system. Firing $122 \mathrm{~mm}$ rockets, up to 720 in each salvo, it can essentially kill and destroy everything in a $300 \mathrm{~m} \times 300 \mathrm{~m}$ area with each salvo. However, this inaccurate system will see many of the rockets fired falling outside the target area. At its maximum range, its projectiles can only individually be aimed at a circle with a $90 \mathrm{~m}$ radius, and half the projectiles will fall outside that area. When used in populated areas, it has indiscriminate effects as it is designed as an area destruction weapon, incapable of pinpoint aiming. ${ }^{11}$

\section{EXAMPLES OF EXPLOSIVE WEAPONS USE IN YEMEN}

Since the Saudi-led intervention began in 2015, it has been causing civilian casualties through explosive weapons use. Whether or not these are directly identifiable as violations of International Humanitarian Law or International Human Rights Law, the pattern of attacks in urban and other populated areas, with consequent systematic damage to civilian infrastructure and attendant civilian casualties, shows a disregard for the Protection of Civilians.

Saudi and UAE-Led Coalition airstrikes on civilians and civilian objects and infrastructure have been recorded since March 2015.12 Two early examples were the destruction of an Oxfam warehouse in Sanaa, and a northern solar powered water system providing water for several villages. The Yemen Data Project has shown a very high proportion of attacks hitting civilian areas. ${ }^{13}$ Such airstrikes continue to be documented on an almost daily basis. ${ }^{14}$

In 2016, as the intense battle for control of Taiz raged, eyewitnesses reported the use of artillery, rockets, mortars and IEDs without regard for the presence of civilians. ${ }^{15}$ Monitoring showed 2,361 incidents of armed violence with direct civilian impact in 2018. ${ }^{16}$ Hudaydah airstrikes caused the majority of casualties, and the majority of civilians who died were killed in their own homes.

Houthi forces have fired artillery shells into populated areas of Saudi Arabia since the conflict began. For example, in July 2017 they fired into the border city of Jizan in an attempt to attack two military bases. ${ }^{17}$ In 2016 , a Houthi rocket was fired at a power station inside Saudi Arabia, killing a three-year-old boy. ${ }^{18}$ The Houthis have regularly fired ballistic missiles at Saudi Arabia, including at Najran and Riyadh. Their missiles are too inaccurate to target military objectives at long distance, thus putting civilians at great risk. ${ }^{19}$

In October 2018, a farmers' market was destroyed by an airstrike, an example of the impact of the conflict on the civilian food supply in Hudaydah. ${ }^{20}$ The World Food Programme reported shelling at grain storage facilities in Hudaydah port which, while not destroying stores, has interrupted supplies. ${ }^{21}$ 
In late 2018, the fiercest fighting in Yemen was in the vicinity of Hudaydah port and city. Amnesty International documented the use of explosive weapons by both Houthis (primarily artillery) and the Coalition (tank shells, airstrikes), especially in battles close to Al Thawra hospital, which has a maternity ward and paediatric intensive care facilities. In 2019, Al Hudaydah still accounts for the majority of civilian casualties, with most of the remaining civilian casualties in Taiz, Hajjah, Amanat al Asimah and AlDhale'e. ${ }^{22}$

In September 2019, 16 civilians, including 7 children, were killed in an attack on an apartment in Al Fakher, in the southern district of Qataba. This is all too typical of incidents in this war. ${ }^{23}$ While provisional 2019 data shows a 42\% reduction in civilian casualties, due to the Stockholm Agreement and the ceasefire in Al Hudaydah, over 75 civilians are still being killed each week. ${ }^{24}$

There are many other examples that could be cited, but the key point is that the UN Group of Eminent Experts report in August 2018 found 'little evidence of any attempt by parties to the conflict to minimize civilian casualties', with Coalition air strikes being found to have caused most of the direct civilian casualties. The Group also found reasonable grounds that the Coalition's 'severe naval and air restrictions in Yemen' constitute a violation of the proportionality rule of International Humanitarian Law. ${ }^{25}$ In September 2019, launching the 2019 report, members of the Group said, 'Five years into the conflict, violations against Yemeni civilians continue unabated, with total disregard for the plight of the people and a lack of international action to hold parties to the conflict accountable. ${ }^{26}$

\section{GENDERED IMPACT OF EXPLOSIVE WEAPONS USE ON WOMEN}

The use of explosive weapons has a gendered impact in many different ways. States transferring arms to other States involved in combat in populated areas, a striking feature of modern warfare, must take these gendered impacts into account as part of GBV risk assessment. For example, research by United Nations Mine Action Service (UNMAS) has shown that female survivors of landmine explosions tend to suffer greater stigma than men as a result of injury, disfigurement or disability. Lack of access to medical care (common in situations where explosive weapons are being used in urban areas) exacerbates threats to women's health in pregnancy and childbirth. Lack of access to clean water (common where explosive weapons have destroyed energy and water infrastructure) can lead to the spread of disease, which is especially dangerous to babies or young children, or to new mothers with suppressed immune systems due to fatigue. Lack of access to safe drinking water can also interrupt lactation. ${ }^{27}$

Wider societal effects also result from the use of explosive weapons. In Afghanistan, Iraq and Syria, increased domestic violence has been shown to result where men are unable to provide for their family. In these societies, it is much harder for women to access work, and it is therefore much more difficult for women to fulfil the role of single household provider if their partner is killed in conflict.

The use of explosive weapons in populated areas is a huge driver of displacement in conflict. Displaced women have a higher risk of exposure and exploitation than men, particularly of being subject to GBV. Research ${ }^{28}$ shows that during conflict and militarization of societies there is often an increase in sexism and violence towards women, and therefore also an increase in the risk of sexual violence, which usually goes unpunished. Women who are displaced or separated from their families and communities are therefore at greater risk of harassment, domestic violence, rape, 


\section{EFFECTS OF THE CONFLICT ON WOMEN IN YEMEN}

The impact of the conflict in Yemen on women has been particularly striking, and goes far beyond the immediate casualty consequences of death and injury. According to the UNHCR, there are 3.65 million internally displaced persons (IDPs) in Yemen - 76\% of whom are women and children. ${ }^{29}$

Women and children account for some $33 \%$ of direct casualties, a high figure given that they are generally not combatants, demonstrating the serious effects of the use of explosive weapons in populated areas. One way in which arms have a direct gendered impact is that pregnant women who are close to explosive weapons blast can miscarry, or may be unable to care for children due to their injuries. ${ }^{30}$ There are also proven long-term mental health impacts of conflict on women as a result of their experiences. ${ }^{31}$

Difficulties in food supply caused by conflict, and challenges facing displaced women and children in accessing aid because of combat and other reasons, contribute to the ongoing crisis. By 2017, some 1.1 million pregnant or lactating women in Yemen were suffering from Moderate Acute Malnutrition (MAM), while Global Acute Malnutrition (GAM) rates were as high as $31 \%$ in some locations. ${ }^{32}$ This has a serious effect on child disease and mortality, particularly infant mortality, as lactation becomes impossible for malnourished women and accessing food for infants can also be impossible. ${ }^{33}$

Soud's story exemplifies the multiple impacts of explosive weapons use. Forced to flee her home because of bombing, Soud lives in Jabal Zaid camp for IDPs, where the conflict has continued to cause devastation. Two of Soud's children (girls, aged three and four) were killed by an airstrike while they were playing in their tent. Two of her sons (aged five and six) died of measles. Soud, who has suffered from a disability since the airstrike killed her daughters, cannot afford to see a doctor or buy medications that she and her surviving children need. While the conflict continues, IDPs like Soud are living in catastrophic humanitarian conditions. ${ }^{34}$

According to the World Health Organization (WHO), only $50 \%$ of health facilities in Yemen are functioning and these face severe shortages of medicines, equipment and staff. These gaps especially affect critical services for the most vulnerable women and children. ${ }^{35}$ This is illustrated by the situation in Hudaydah, where there has been intense fighting, including bombing and artillery fire close to the AI Thawra hospital. The maternity ward and paediatric intensive care unit have been badly affected. Women have been unable to reach the hospital to give birth, increasing the risk of maternal and infant mortality, and depriving newborns who do survive of important medical supervision. ${ }^{36}$

As early as 2015, the United Nations Population Fund reporting women living in poverty in IDP camps, where they were much more vulnerable than men to hunger, malnutrition and lack of shelter, as well as being subjected to GBV from family members and fighters. ${ }^{37}$ This situation continues and has worsened. In 2018, UN Women reported:

'Yemeni women and girls are the ones who are paying the price of war. Some 76 per cent of internally displaced persons are women and children, and nearly 
21 per cent of households of internally displaced persons as well as host communities are headed by women below the age of $18 .{ }^{\prime} 38$

The effects of the war have reinforced pre-existing barriers for women. Social norms across Yemen are conservative, with women traditionally the primary caregivers at household level, responsible for crop cultivation and livestock farming, as well as cooking, cleaning, collecting water and firewood, and caring for children and elderly people, those who are sick, and people with disabilities. Despite this traditional view of a woman's role, according to UN Women:

'Yemeni women are now having to step into roles that were traditionally filled by men because so many men have been killed or injured, forcibly disappeared or have lost their jobs. But now they have the double burden of being the family's main provider while also performing their expected role of primary caregivers in the family.' ${ }^{\prime} 9$

There is some evidence that this situation has led to increased domestic violence against women. There is also evidence of a rise in polygamy, and increased sale of daughters for marriage dowry because of poverty. ${ }^{40}$ For example, 13-year-old Malak had to marry to save her younger brother Shadi, around five years old, who lost his leg in the conflict and needed a prosthetic one. The family fled the fighting and are now living in an IDP camp. Malak and her mother said they would not have accepted the marriage if they lived in better conditions; they had to do it to pay off their debts and help cover Shadi's medical treatment and other expenses. ${ }^{41}$

Reinforcing this trend, the war has also reversed gains made in the previous decade in education for girls. Only 53\% of Yemeni women were literate in 2013, and as early as 2015 there was a $66 \%$ increase in girls dropping out of education because of the conflict. ${ }^{42}$ Women have faced growing restrictions on movement as more conservative religious views become prevalent. The need for a mahram, a male guardian, to accompany a woman when she leaves the house, is becoming more widespread. ${ }^{43}$

\section{According to UN Women:}

'The most urgent issues for women include the lack of medical care and the consequences of economic devastation. Women and children also account for the largest number of civilian victims. Reported gender-based violence incidents increased by 36 per cent in 2017, and child marriage rates have escalated to 66 per cent, as of 2017. The dreams of many Yemeni women and girls have not come true, just because they are women and girls living in Yemen.' 44

The UN OCHA website Humanitarian Response details the particular difficulties that women IDPs face in Yemen. ${ }^{45}$ Most likely to be displaced by the use of explosive weapons as a result of the conflict, women face additional barriers to registering as IDPs, as they are more likely than men to be illiterate, less likely to have the ID necessary to register, and in some areas cannot register without being accompanied by a male relative (but may have none). This restricts women's access to food, water, medicine and shelter.

Throughout the war, the WHO has gathered testimony from IDPs to highlight how the conflict affects women, including the following: 46

'Sama has been in Abu Bakr school since last June. She had to sleep on the floor before being assigned a classroom... Her sister and mother are the only family she has got and they have no support. "We ran away with nothing but our purses and the clothes on our backs," Sama's sister says. Sama needs all the quiet she can get because she suffers from a brain tumour. "She keeps 
losing consciousness, if not for the help of charitable donors, she wouldn't be able to get her daily dose of medicine," adds Sama's mother.' ${ }^{4}$

'Nada is a mother of four and was displaced from Al Mina district in AlHudaydah. She took an overcrowded bus to Sana'a. Upon her arrival, she had nowhere to go. Prior to the conflict, Nada had nothing and was hardly able to provide the day to day necessities for her family. "We heard the sounds of aircrafts and missiles hitting the city, and the battle tanks were already in the neighbourhoods. I was terrified for my family and I had to leave," says Nada while describing the situation after the armed conflict had gripped the city. Nada's daughter is sick and lays on this mattress which she shares with her three brothers and sisters and mother. They have to sleep in the school corridor until they get a classroom. "Hospitals and pharmacies were closed; people didn't know where to go. It was a ghost town. All you could hear was the shelling," she added. Nada does not have a room, so she sits on one of the school corridors where her 2-year-old lies sick on a mattress they all share. "I don't know what she is sick with, and I can't afford medical care. We have nothing; we are not part of this. Yet we bear the burdens of this war."'48

\section{GENDERED IMPACT OF EXPLOSIVE WEAPONS USE ON MEN}

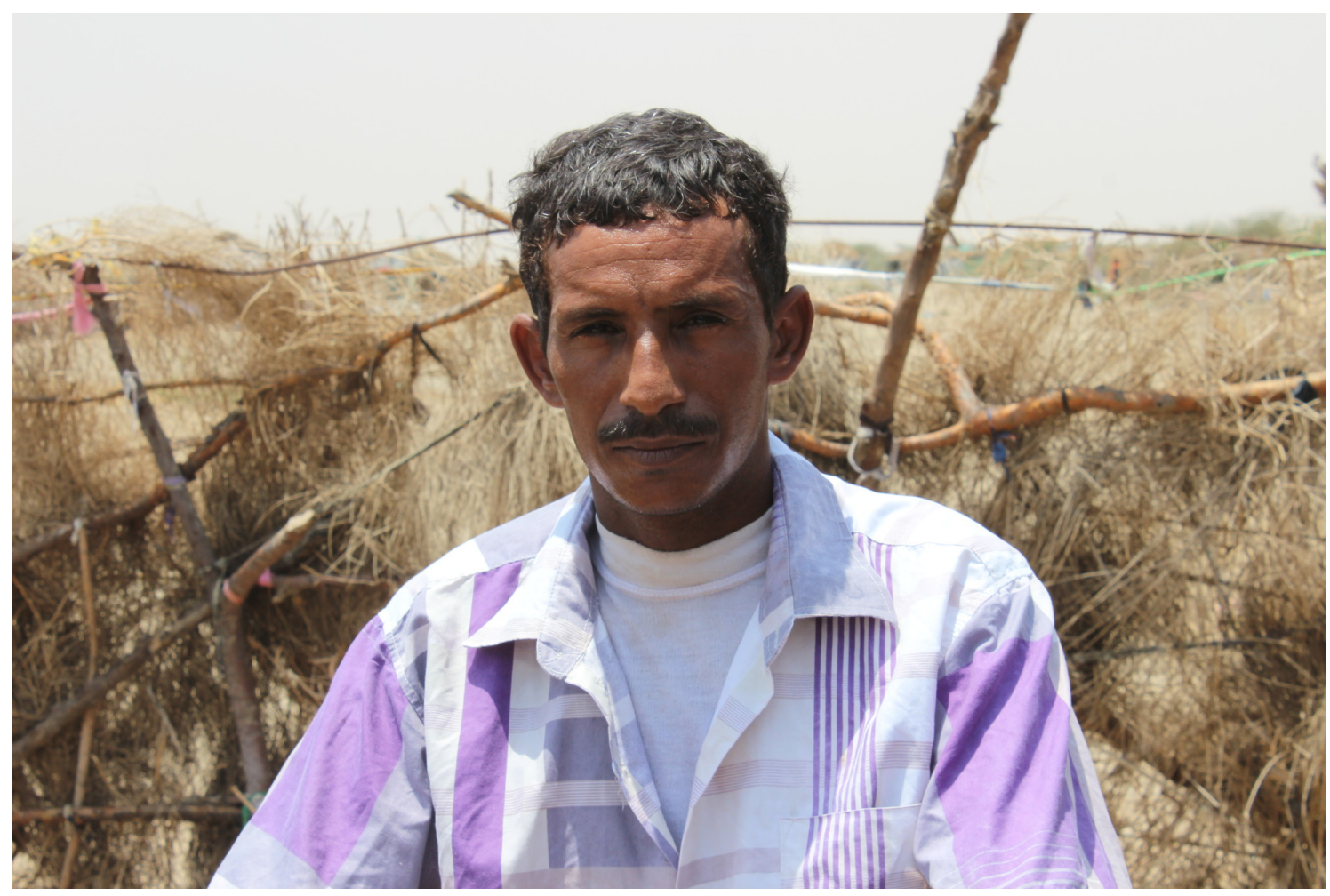

Abdo Mohammed works in a small spare parts shop to make ends meet. A father of eight children, he had to flee his house in Haradh in Northern Yemen due to airstrikes close to the Saudi border. This meant losing his daily income of 5,000 Yemeni riyals (around \$20). Assistance from Oxfam's unconditional cash transfer programme allowed him to buy some food. By selling spare parts, he can now make 800 to 2,000 riyals a day (between $\$ 3$ and $\$ 8$ ). He also helps the community by driving a tractor in the fields during the harvest season, which brings in a bit of extra money. Photo: Moayed Al Shaibani/Oxfam.

There are a number of ways in which men and boys are likely to suffer a gendered impact from the use of explosive weapons. 
While gender-disaggregated data on deaths from the use of explosive weapons in populated areas, and in conflict in general, is lacking, it is generally thought that men make up the majority of direct victims of armed violence, ${ }^{49}$ and of explosive weapons specifically. This is particularly the case for men of fighting age, from about 15-40 years. Men are more likely than women to be combatants, either through choice or societal or economic pressure. Sometimes men are targeted just for being men. ${ }^{50}$

The Women's International League for Peace and Freedom has written that:

'The blanket categorisation of adult men as militants raises moral, legal, social, and policy concerns in a number of areas:

- It erodes the protection that civilians should be afforded in armed conflict and violates many human rights, including the rights to life and due process;

- It undermines accurate casualty recording, which is a crucial basis for military, legal, and political analysis of attacks and for evaluating the use of force more generally;

- It suggests that sex can be taken as a key signifier of identity, which constitutes a form of gender-based violence and has broader implications in the reinforcement of gender essentialisms and problematic associations of masculinity with violence; and

- It sets a precedent for blanket categorisations of people, which may have problematic implications as certain states move to develop and deploy weapons systems operating with greater autonomy in the identification of targets. ${ }^{.51}$

WILPF's analysis indicates that this represents a form of GBV which should be taken into account when assessing the legality of a proposed arms transfer, as per the Arms Trade Treaty.

In conservative societies, men are more likely than women to buy and sell items at markets, which are often attacked. They are also more likely to be rescue workers and to die or be injured during the collapse of buildings after explosive weapons attacks, or to be casualties of secondary attacks which are deliberately designed to target emergency services.

These gendered impacts specific to men are less frequently considered than those affecting women, which receive far greater attention from the international community. This in itself is another factor that exacerbates GBV.

\section{IMPACT OF EXPLOSIVE WEAPONS ON CHILDREN}

Children are more likely than adults to mishandle explosive items like landmines, cluster bombs or other unexploded ordnance left behind after a war. Children therefore represent a large proportion of victims of such munitions; for example, they accounted for $38 \%$ of civilian casualties globally in $2015 . .^{52}$ In past years, children have accounted for as many as $46 \%$ of civilian casualties of explosive remnants of war (ERW). ${ }^{53}$ Boys are more likely than girls to take part in outdoor activities (such as herding livestock, gathering wood and food, or collecting scrap metal) in many countries contaminated with mines/ERW. This exposes them to a greater risk of contact, and boys represent around $80 \%$ of child casualties of ERW. ${ }^{54}$ 


\section{A CLOSING POLITICAL SPACE FOR WOMEN}

Women played an important role in the street demonstrations in 2011, challenging traditional gender roles. ${ }^{55}$ The award of the Nobel Peace Prize to the Yemeni journalist and human rights activist Tawakkol Karman showed strong international support for the inclusion of women in the National Dialogue of 2013-14. The Dialogue opened up political space for Yemeni women, with $30 \%$ of places in the Dialogue reserved for women across all constituencies (although it is worth noting that the Houthis refused to include women at all). Three of the nine working groups of the Dialogue were chaired by women. The requirement for $90 \%$ approval before the adoption of resolutions in the Dialogue process meant that they could not be passed without the approval of women participants.

The National Dialogue discussed many issues related to gender inequality, including increasing the age of marriage to 18 years, a $30 \%$ quota for women in Parliament, the right to education, paid maternity leave and criminalization of violence against women and sex trafficking. Women who participated in the National Dialogue reportedly also experienced substantial empowerment through networking, developing new political skills and learning to lobby, including the ability to speak out in the company of men, which many had never done before. ${ }^{56}$

However, since the upsurge in violence in 2014, and especially since the intervention by the Saudi and UAE-Led Coalition in 2015, the involvement of women in peace processes has shrunk to the extent that women have effectively been marginalized. In early talks there were no women representatives at all, and in peace talks in Kuwait in 2016 , only three of the 26 delegates were women. De-escalation committees formed to reduce violence have no women representatives. ${ }^{57}$

The lack of women's representation has been exacerbated by the approach of Special Envoy Martin Griffith, who has chosen to engage the combatant parties alone rather than including a broader spectrum of Yemeni society. This is in stark contrast to the approach taken by his predecessor Jamal Benomar, who took a strong stand in favour of women's engagement. Since there is plenty of evidence that durable peace agreements are much better built with full societal engagement, especially with the participation of women, this is regrettable and Yemeni women must be fully engaged as soon as possible. ${ }^{58}$

However, despite these obstacles to participation in the formal peace negotiations, women are still engaged in peace activities. UK Aid reports the following, based on research by Oxfam and Women's International League for Peace and Freedom (WILPF):

- 'In Aden, women are focusing on countering violent extremism and radicalization, supporting social cohesion, disarmament and reintegration of combatants including children, and promoting psychosocial support and relief. This includes conducting awareness sessions on disarmament for a city free of weapons, observing early warning signs of radicalization among youth, and conducting awareness sessions to deradicalize.

- In Taiz, women have been involved in negotiating with militia leaders for the release of prisoners of war, including through negotiating across kinship groups they are tied to through marriage.

- In Sana'a, women have organized themselves to advocate for the release of detainees. 
- In Aden, Abyyan and Taiz, women have been active in community committees formed to distribute aid and help to provide basic services. These committees are often supported by international NGOs.' 59

Women are also active in small numbers as combatants, and in combat support roles such as arms smuggling or transport of food, water and other supplies for fighters. ${ }^{60}$

\section{PROTECTION OF CIVILIANS AND THE USE OF EXPLOSIVE WEAPONS IN POPULATED AREAS}

States and non-State actors alike have a duty to ensure the Protection of Civilians in conflict. According to UN OCHA:

'Protection encompasses all activities aimed at ensuring full respect for the rights of the individual in accordance with human rights law, international humanitarian law (which applies in situations of armed conflict) and refugee law. States have the primary responsibility to protect people within their jurisdiction. [...] In situations of armed conflict, all parties to the conflict, i.e. States and organized armed groups, must respect and protect civilians. This includes ensuring they are spared from the effects of fighting and have access to food, medical and other basic services. When national authorities or other parties to conflict are unable or unwilling to meet these obligations, humanitarian organizations may - with the parties' consent - provide assistance to the affected population. In addition, such organizations may undertake advocacy to promote the rights of the population and encourage the primary duty-bearers to meet their obligations. ${ }^{61}$

It is increasingly recognized that the use of explosive weapons in populated areas is incompatible with the need to assure Protection of Civilians. Intense bombing of urban areas puts civilians at risk, often without the military forces even being aware that civilians are present, as they are hiding from fighting. The risks to civilians are detailed earlier in this paper.

The duty to assure Protection of Civilians goes deeper than the need to adhere scrupulously to International Humanitarian Law and International Human Rights Law. Combatant parties must do all they can to avoid the use of explosive weapons especially those with wide area effects, or inherently indiscriminate weapons like multiple rocket launchers or IEDs - in populated areas. It is essential to avoid civilian deaths and injuries, and to prevent the full range of negative effects of the use of explosive weapons discussed in this brief. Where current policies are failing to achieve this objective, as they are in Yemen, they must be changed.

\section{POLICY CONSIDERATIONS}

The use of explosive weapons in populated areas of Yemen is directly contributing to the ongoing humanitarian crisis, including causing civilian deaths and injuries as well as longer-term impacts from destruction of and damage to vital infrastructure and essential services such as housing, hospitals and medical facilities, schools, power supplies, water and sanitation systems. All parties to the conflict should take on board the UN Secretary-General's call to avoid the use of explosive weapons with wide area effects in populated areas. ${ }^{62}$ Furthermore, States should support the development of an international political declaration to address this harm. 
Of relevance to the Arms Trade Treaty and wider International Humanitarian Law responsibilities, none of the effects of explosive weapons use in Yemen would be possible if arms suppliers - including the UK, US, France, Italy and Iran - stopped the transfer of such weapons to all combatants. Of particular concern in this regard is the use of explosive weapons with wide area effects. Restrictions on the transfer of such weapons for use in conflicts such as the one in Yemen must take account of this. The bar to be crossed before transfer must be a high one.

States that are party to the Arms Trade Treaty should be specifically assessing the risk of GBV alongside the risk of other breaches of International Humanitarian Law. Any reasonable assessment would have to conclude that a risk of such abuses exists. There needs to be a thorough discussion of the definition of GBV, as the Treaty does not define the term. The Treaty also requires an assessment of risk of violence against women and children, and the particular risks for children resulting from explosives weapons use is an important part of this.

Oxfam is convinced that these risk assessments have to go beyond examining attacks which are in themselves a breach of International Humanitarian Law, and look at the wider gendered impact of the use of explosive weapons as part of a thorough examination of the potential consequences of the use of transferred explosive weapons. This is an essential component of reducing humanitarian harm in conflict, which the Arms Trade Treaty was designed to do.

It is clear from the effects of the conflict on women and families, and in particular the effects of explosive weapons, that current transfer policies have failed and that GBV and other gendered impacts of the use of explosive weapons need to be taken more seriously. A discussion of how that can be done is vital. From a Protection of Civilians perspective, narrow adherence to International Humanitarian Law or International Human Rights Law is far from sufficient. A thorough assessment of the humanitarian catastrophe facing all Yemenis and the role of outside States in prolonging and intensifying the conflict shows that if peace is to be achieved and Yemen rebuilt, then far stricter guidelines on preventing civilian harm must be followed, and far more account taken of Yemeni people's needs. One essential element of this would be to put in place comprehensive mechanisms to track civilian harm and record civilian casualties to establish the full scale of the problem.

Yemen needs a comprehensive and inclusive peace process, in which Yemeni women play a full role. This should be built on the basis of the National Dialogue, which successfully engaged women at every level and took account of women's needs, as well as the work of former Special Envoy Jamal Benomar in negotiating during the conflict.

All combatant parties and allied or supporting States and non-State actors must do all they can to fully assure the Protection of Civilians in the widest possible sense.

In the interests of the Yemeni people, Oxfam believes that the only viable course of action is to halt the transfer of arms to any and all combatants in Yemen where an overriding risk remains that those arms will be used in the current conflict, and to force all combatants to engage meaningfully and urgently in a process of peace, reconciliation and rebuilding. 


\section{NOTES}

1 See the ICRC commentary on the State responsibility for violations of International Humanitarian Law, which says: 'Violations of international humanitarian law are often committed with weapons provided by third States. As long as the use of those particular weapons is not prohibited a State providing them is not responsible for violations of international humanitarian law committed by the receiving State with such weapons. However, once it knows that the receiving State systematically commits violations of international humanitarian law with certain weapons, the aiding State has to deny further transfers thereof, even if those weapons could also be used lawfully.' https://www.icrc.org/en/doc/assets/files/other/401 434 sassoli.pdf

2 See, inter alia, the commentary of the International Committee of the Red Cross and Red Crescent Societies (ICRC) on this at: https://ihl-databases.icrc.org/customaryihl/eng/docs/v1 rul rule15, accessed on 15 May 2019.

3 See Lt. J.F.S Millwood Hargrave BSc (September 2017) The Impact of Blast Injury on Children: A Literature Review. The Royal British Legion Centre for Blast Injury Studies, Imperial College, London. https://www.imperial.ac.uk/media/imperial-college/researchcentres-and-groups/centre-for-blast-injury-studies/Literature-Review-on-paediatric-blastinjury.pdf

4 For examples, see PAX and Article 36 (June 2018) Explosive Weapons - Factors that produce wide area affects. http://www.article36.org/wp-content/uploads/2018/07/WAE-Harm-TableFinal-Version.pdf

5 Geneva International Centre for Humanitarian Demining (GICHD) (February 2017) Explosive Weapons Effects: Final Report. http://characterisationexplosiveweapons.org/studies/finalreport/. Information on secondary and tertiary effects of explosive weapons also drawn from this source.

6 Department of the Army. (2016). Infantry Platoon and Squad. See Appendix C: Indirect Fire Support Planning. https://armypubs.army.mil/epubs/DR pubs/DR a/pdf/web/ATP\%20321x8\%20FINAL\%20WEB\%20INCL\%20C1.pdf

7 GICHD, op cit.

8 Action on Armed Violence (AVOV) (March 1, 2016). Explosive weapons with large destructive radius: air-dropped bombs (the Mark 80 series and Paveway attachments). https://aoav.org.uk/2016/large-destructive-radius-air-dropped-bombs-the-mark-80-seriesand-paveway-attachments/

9 USA War Office, Department of the Army (April 1957) Field Artillery Gunnery. http://www.bits.de/NRANEU/others/amd-us-archive/FM6-40\%2857\%29.pdf

10 GlobalSecurity.org. https://www.globalsecurity.org/military/world/russia/9a52.htm

11 Military-Today.com. http://www.military-today.com/artillery/bm21u grad.htm and Army Recognition:

https://www.armyrecognition.com/russia russian_army vehicles system artillery uk/bm$21 \mathrm{grad} 9 \mathrm{k} 51 \mathrm{mlrs} 122 \mathrm{~mm}$ multiple launch rocket system data.html; PAX and Article 36 (October 2016) Areas of Harm: Understanding explosive weapons with wide area effects. https://www.paxforpeace.nl/publications/all-publications/areas-of-harm

12 Human Rights Watch (July 11, 2016) Bombing Businesses: Saudi Coalition Airstrikes on Yemen's Civilian Economic Structures. https://www.hrw.org/report/2016/07/11/bombingbusinesses/saudi-coalition-airstrikes-yemens-civilian-economic-structures

13 The Guardian (September 16, 2016) One in three Saudi air raids on Yemen hit civilian sites, data shows. https://www.theguardian.com/world/2016/sep/16/third-of-saudi-airstrikes-onyemen-have-hit-civilian-sites-data-shows

14 Reuters (August 28, 2018) Some Saudi-led coalition air strikes in Yemen may amount to war crimes - U.N. https://uk.reuters.com/article/uk-yemen-security-un-rights/some-saudi-ledcoalition-air-strikes-in-yemen-may-amount-to-war-crimes-u-n-idUKKCN1LD0L9

15 BBC (December 1, 2016) Yemen conflict: Terror of life under siege in Taiz. https://www.bbc.co.uk/news/world-middle-east-38152428 
16 For details see the Civilian Impact Monitoring Report, January - December 2018, Protection Cluster Yemen.

https://reliefweb.int/sites/reliefweb.int/files/resources/civilian impact monitoring report annu al 2018 2.pdf

17 Xinhuanet (July 17, 2017) Yemen's Houthi rebels fire artillery on Saudi border city. http://www.xinhuanet.com/english/2017-07/17/c 136448321.htm

18 TheNewArab (August 28, 2016) Three-year-old killed in cross-border Houthi attack on Saudi Arabia. https://www.alaraby.co.uk/english/news/2016/8/27/three-year-old-killed-in-crossborder-houthi-attack-on-saudi-arabia

19 The National (June 24, 2018) Saudi air defences intercept missiles over Riyadh. https://www.thenational.ae/world/mena/saudi-air-defences-intercept-missiles-over-riyadh$\underline{1.743809}$

20 Aljazeera.com (October 24, 2018) Deadly air attack hits vegetable market in Hodeidah. https://www.aljazeera.com/news/2018/10/deadly-air-strike-hits-vegetable-market-hodeidah$\underline{181024181609517 . \mathrm{html}}$

21 Reuters (November 11, 2018) Street battles rage in Yemen's Hodeidah, civilians caught in crossfire. https://uk.reuters.com/article/uk-yemen-security/street-battles-rage-in-yemenshodeidah-civilians-caught-in-crossfire-idUKKCN1NG0ML?rpc $=401 \&$

22 See Reliefweb (June 23, 2019) Yemen: Protection Cluster Update, op cit.

23 Middle East Eye (September 24, 2019) Saudi coalition air strikes kill seven children in Yemen. https://www.middleeasteye.net/news/saudi-led-coalition-air-strikes-kills-sevenchildren-yemen

24 Reliefweb (June 23, 2019) Yemen: Protection Cluster Update (June 2019). https://reliefweb.int/report/yemen/yemen-protection-cluster-update-june-2019

25 UN Human Rights Council (August 28, 2018). Yemen: United Nations Experts point to possible war crimes by parties to the conflict. https://www.ohchr.org/EN/HRBodies/HRC/Pages/NewsDetail.aspx?NewsID=23479\&LangID =E

26 UN Human Rights Council (September 3, 2019) Yemen: Collective failure, collective responsibility - UN expert report. https://www.ohchr.org/EN/HRBodies/HRC/Pages/NewsDetail.aspx?NewsID=24937\&LangID $\underline{\underline{E}}$

27 See, for example, Reaching Critical Will of the Women's International League for Peace and Freedom (2014) Women and Explosive Weapons. http://www.reachingcriticalwill.org/resources/publications-and-research/publications/8629women-and-explosive-weapons

28 See, for example, Sidebotham et al. (June 2016) Sexual violence in conflict: a global epidemic, The Obstetrician \& Gynaecologist. https://obgyn.onlinelibrary.wiley.com/doi/pdf/10.1111/tog.12314; or E.J. Wood (2015) Conflict-related sexual violence and the policy implications of recent research, International Review of the Red Cross. https://www.icrc.org/en/download/file/12237/irrc-894-wood.pdf.

29 See UN Women (September 12, 2018) Take five: "Yemeni women and girls are the ones who are paying the price of war". http://www.unwomen.org/en/news/stories/2018/9/take-five-areejjamal-al--khawlani and Reliefweb (April 7, 2019) Yemen: UNHCR Operational Update, 5 April 2019. https://reliefweb.int/report/yemen/yemen-unhcr-operational-update-5-april-2019

30 The Associated Press (December 7, 2018) Civilian Casualties in Yemen Average 123 per Week, UN Says. https://www.haaretz.com/middle-east-news/civilian-casualties-in-yemenaverage-123-per-week-un-says-1.6724335

31 See, for example, R. Jewkes, N. Jama-Shai and Y. Sikweyiya (2017) Enduring impact of conflict on mental health and gender-based violence perpetration in Bougainville, Papua New Guinea: A cross-sectional study. PLoS One. 2017. https://www.ncbi.nlm.nih.gov/pmc/articles/PMC5656319/

32 N. Al Dheeb, A. Ziolkovska and S. Chitekwe (2018). Experiences of implementing CMAM [community-based management of acute malnutrition] in Yemen and number of deaths averted. Emergency Nutrition Network. https://www.ennonline.net/fex/58/cmamyemenaverteddeaths 
33 UN OCHA Yemen page: https://www.unocha.org/yemen; Reliefweb (October 25, 2018) Dozens of civilians killed and injured as a result of attacks in Hodeidah. https://reliefweb.int/report/yemen/dozens-civilians-killed-and-injured-result-attacks-hodeidahenar

34 Information gathered from an interview by Oxfam staff in January 2019.

35 USAID (September 11, 2019) Yemen Health Fact Sheet. https://reliefweb.int/report/yemen/yemen-health-fact-sheet-september-2019

36 Reuters (November 8, 2018) Fighting nears hospital in Yemen's Hodeidah, trapping young patients. https://www.reuters.com/article/us-yemen-security/fighting-nears-hospital-inyemens-hodeidah-trapping-young-patients-idUSKCN1ND1PN

37 UNFPA (November 2, 2015) As Yemen conflict drags on, women's vulnerability grows. https://www.unfpa.org/es/node/13382

38 UN Women (September 12, 2018) Take five. Op. cit.

39 Ibid.

40 W. Gressman (October 2016) From the Ground Up: Gender and conflict analysis in Yemen. Oxfam. https://policy-practice.oxfam.org.uk/publications/from-the-ground-up-gender-andconflict-analysis-in-yemen-620112.

41 Names changed. Information gathered from interview by Oxfam staff in January 2019.

42 Gressman (2016) op. cit., and Ministry of Public Health and Population and Central Statistical Organization et al. (2015) Yemen: National Health and Demographic Survey 2013, Rockville, Maryland, USA: MOPHP, CSO, PAPFAM, and ICF International. https://dhsprogram.com/pubs/pdf/FR296/FR296.pdf

43 Gressman (2016) op. cit.

44 UN Women (September 12, 2018) op. cit.

45 OCHA Services/Yemen. Gender, age and diversity in IDP Registration. https://www.humanitarianresponse.info/en/operations/yemen/gender-age-and-diversity-idpregistration

46 The WHO has recorded many similar stories throughout the war. http://www.emro.who.int/yem/yemen-news/displaced-people-in-ibb-devastated-by-hungerand-diseases-for-3-years.html

47 World Health Organization (October 8, 2018) Internally displaced persons from Hudaydah endure harsh circumstances in Sana'a. http://www.emro.who.int/yem/yemennews/hudaydah-idps-in-sanaa-endure-harsh-circumstances-since-3-months.html

48 Ibid.

49 PRIO (2009) Armed Conflict Deaths Disaggregated by Gender. http://www.css.ethz.ch/en/services/digital-library/publications/publication.html/109997

50 See, for example, this report of the US Army Center for Lessons Learned paper on Civilian Casualties in Afghanistan: The Nation (September 18, 2013) America's Lethal Profiling of Afghan Men. https://www.thenation.com/article/americas-lethal-profiling-afghan-men/

51 Article 36 and Reaching Critical Will (a programme of Women's International League for Peace and Freedom) (October 2014) Sex and Drone Strikes: Gender and identity in targeting and casualty analysis.

http://www.reachingcriticalwill.org/images/documents/Publications/sex-and-drone-strikes.pdf

$52 \mathrm{E}$. Laws (2017) The impact of mines and explosive remnants on war of gender groups. K4D Helpdesk Report. Brighton, UK: Institute of Development Studies. https://assets.publishing.service.gov.uk/media/59844e0c40f0b61e4b00005c/149-the-impactof-mines-and-explosive-remnants-of-war-on-gender-groups 1 .pdf

53 Ibid.

54 Ibid. 
55 Women's International League for Peace and Freedom (WILPF) (2017) Feminism at the frontline: Addressing women's multidimensional insecurity in Yemen and Libya.

https://www.wilpf.org/portfolio-items/feminism-at-the-frontline-addressing-womensmultidimensional-insecurity-in-yemen-and-libya/

56 Coomaraswamy et al., Preventing Conflict, Transforming Justice, Securing the Peace: A Global Study on the Implementation of United Nations Security Council resolution 1325. UN Women, 2015. https://www.peacewomen.org/sites/default/files/UNW-GLOBAL-STUDY-13252015\%20(1).pdf

57 For a fuller discussion of the National Dialogue process, see UK Aid (February 2, 2018) VAWG Helpdesk Research Report 158: Women, Peace and Security in Yemen. https://assets.publishing.service.gov.uk/media/5c5964eaed915d04352fed43/VAWG Helpdes k 158 - WPS and VAWG in Yemen FINAL.pdf

58 J. Krause, W. Krause and P. Bränfors (2018) Women's Participation in Peace Negotiations and the Durability of Peace. International Interactions, 44:6, 985-1016, DOI: https://doi.org/10.1080/03050629.2018.1492386

59 See the UK Aid briefing paper on Yemen at https://assets.publishing.service.gov.uk/media/5c5964eaed915d04352fed43/VAWG Helpdes k 158 - WPS and VAWG in Yemen FINAL.pdf

60 See, for example, S. Anderlini et al. (2017) Bringing peace to Yemen by having women at the table: What the U.S. must do and why it matters, U.S. Civil Society Working Group on Women, Peace, and Security, Policy brief August 2017.

http://www.icanpeacework.org/2017/10/11/bringing-peace-yemen-women-table/; and K. Anderson and $\mathrm{H}$. Myrttinen (2017) Now is the time: Research on gender justice, conflict and fragility in the Middle East and North Africa, Oxfam/International Alert/Foreign and Commonwealth Office. https://www.oxfam.org/en/research/now-time-research-genderjustice-conflict-and-fragility-middle-east-and-north-africa

61 OCHA on Message (March 2012) What is Protection? https://www.unocha.org/sites/dms/Documents/120405\%2000M\%20Protection $\% 20$ final\%20d raft.pdf

62 United Nations Security Council (May 14, 2018) Protection of civilians in armed conflict, Report of the Secretary-General. https://reliefweb.int/sites/reliefweb.int/files/resources/N1812444.pdf 
